\title{
Highly Stereoselective Preparation of Nitro Olefins and Nitro Dienes by the Addition-Elimination of Copper-Zinc Organometallics to $\beta$-Alkylthio and $\beta$-Phenylsulfonyl Nitro Olefins
}

\author{
Carole Retherford and Paul Knochel* \\ The Willard II. Dow Laboratories, Department of Chemistry, University of Michigan
}

Ann Arbor, Michigan 48109

Summary: The addition-elimination of copper-zinc organometallics $R C u(C N) Z n X$ to (E)-1-nitro-2-phenylsulfonyl ethylene 2 a gave highly functionalized pure $(E)$ nitro olefins and stereoselectively $(1 E, 3 E)$ and $(1 E, 3 Z)-1-$ nitrodienes in excellent yields. $\beta$-Alkylthio nitro olefins such as 2 -ethylthio-1-nitro-1-cyclohexene $2 b$ and 2,2 -dimethylthio-1-nitroethylene 12 were found to have a similar behavior. This methodology allowed an expeditive preparation of the triene 5 which underwent an extremely mild silica gel-catalyzed, stereospecific Diels-Alder cyclization.

We have recently reported ${ }^{1}$ that highly functionalized nitroalkanes can be prepared by the addition of a wide range of zinc-copper reagents ${ }^{2}(\mathrm{RCu}(\mathrm{CN}) \mathrm{ZnX}) 1$ to nitro olefins in high yields. Nitro olefins having a leaving group in $\beta$-posilion such as a dialkylamino-3 ${ }^{3}$, an alkylthio- ${ }^{4}$ or a phenylsulfonyl ${ }^{5}$-group have been known to undergo addition-elimination ${ }^{6}$ reactions with nucleophiles. Although $\beta$-nitroenamines are able to react with strong nucleophiles ( $R M g X, R L i)$, only the reaction of $\beta$-sulfur-substituted nitro olefins with weak nucleophiles (amines, enolates) has been reported. We have now found that $\beta$-sulfur substituted nitro olefins of type 2 react under very mild conditions with the copper organometallics 1 affording polyfunctional nitro olefins of type 3 in excellent yields ${ }^{7}$ (Scheme $I$ and Table I). Thus the addition of (E) -1-nitro-2-phenylsulfonylethylene $2 \mathrm{a}$ (1 eq.) to a THF solution of $\mathrm{RCu}(\mathrm{CN}) \mathrm{ZnX}\left(1 \mathrm{eq}\right.$.) at $-78^{\circ} \mathrm{C}$ furnishes, after

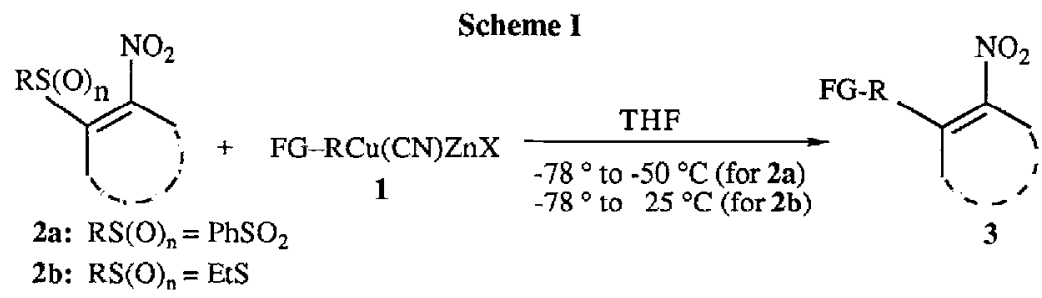

warming the reaction mixture to $-50^{\circ} \mathrm{C}$ for $5 \mathrm{~min}$., the stereoisomerically pure $(E)$-nitro olefins $3 \mathrm{a}-3 \mathrm{~d}$ in $79-87 \%$ yields (entries 1-4 of Table I). The $\alpha$-acetoxy copper-zinc reagent 1e, readily prepared from isobutyraldehyde, acetyl bromide and zinc $^{8}$, allows a unique approach to the interesting $\gamma$-nitro allylic acctates of type $3 e$ (entry 5 ). The cyclic reagent 2-ethylthio-1-nitro-1-cyclohexene $2 \mathrm{~b}$ displays the same type of reactivity, although the addition of RCu(CN)ZnI proceeds only at higher temperatures $\left(-20^{\circ}\right.$ to $\left.25^{\circ} \mathrm{C}\right)$ allowing the preparation of polyfunctional nitrocyclohexenes bearing functional groups such as an ester-, a cyano-, or a phosphonate ${ }^{9}$ group in 79-89\% yields (entries $8,9,10$ ). A highly stereoselective preparation of conjugated 1-nitro-1,3-dienes is also possible. The reaction of the (Z)-alkenylcopper reagent $1 \mathrm{f}$ prepared from $(Z)$-1-iodo-1-hexene ${ }^{10}$ with $2 \mathrm{a}$ gives $(1 E, 3 Z)$-1-nitro-1,3-octadiene $\mathbf{3 f}$ in $98 \%$ stereoisomeric purity. This nitro diene ${ }^{11}$ rapidly isomerizes during a flash chromatography purification; however, its distillation $\left(42^{\circ} \mathrm{C} ; 0.03 \mathrm{mmHg}\right)$ affords a $96 \%$ isomerically pure material in $82 \%$ yield (entry 6 ). Similarly, the reaction of 2 a with the $(E)$-alkenylcopper compound $\mathbf{~ I g}$ provides ( $1 E, 3 E)$-1-nitro-1,3-decadiene $3 \mathrm{~g}$ in $97 \%$ stereoisomeric purity (before chromatography) and $81 \%$ 
yield (entry 7). The cyclic nitro diene $3 \mathbf{k}$ is obtained in $90 \%$ yield by the addition of the $(E)$-alkenylcopper $1 \mathrm{~g}$ to 2-ethylthio-1-nitro-1-cyclohexene $2 \mathbf{b}$ (entry 11). The Michael addition of the 1,3-dienylcopper reagent $12 \mathbf{4}$ to $2 \mathrm{a}$ gives the intermediate nitrotriene 5 which after a short path filtration over silica gel was stirred in hexane over silica gel for 4 hours affording the intramolecular cycloadduct 6 as a single diastereoisomer in $85 \%$ yield. This remarkably mild Diels-Alder reaction proceeds exclusively via an anti transition state (Scheme II). ${ }^{13}$ The silica gel catalysis is essential since the thermic cycloaddition has been shown to be non-stereospecific. ${ }^{13 \mathrm{~d}}$

Scheme II<smiles>CC=CC=CCCC(C)(C)C(=O)OC</smiles>

4<smiles>C/C=C/C=C/CC</smiles>

5<smiles>C[C@H]1C=C[C@H]2CCC[C@H]2[C@H]1[N+](=O)[O-]</smiles>

6: single diastereoisomer $85 \%$ overall yield

The reaction of $2 \mathrm{a}$ with more sterically hindered secondary reagents did not take the expected course. Thus, the reaction of $2 \mathrm{a}$ ( 1 eq.) with the lithium ester enolate 7 (1.05 eq.) afforded as sole product the vinylic sulfone 8 in $75 \%$ yield (THF, $-78^{\circ} \mathrm{C}$, $5 \mathrm{~min}$.; Scheme III). Also, the addition of the copper reagent 9 derived from cyclohexylzinc iodide gave a mixture of the phenylsulfonyl substitution product 10 and the nitro substitution product 11 in $87 \%$ yield (10/11, 19:81). ${ }^{14}$
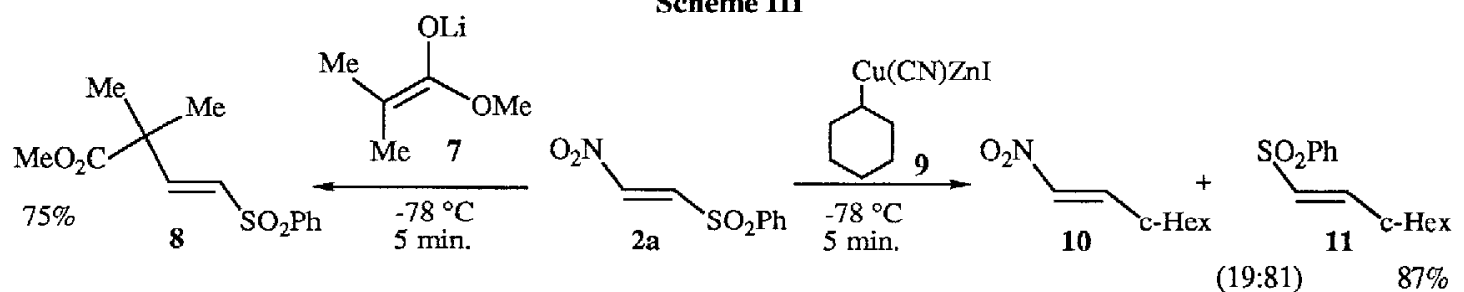

$\beta$-Disubstituted nitro olefins of type $\mathbf{1 3}$, which can usually not be prepared via a nitro aldol reaction (due to the reversibility of this reaction when ketones are used as substrates), are readily obtained by the reaction of commercially available 2,2-dimethylthio-1-nitroethylene $12\left(1 \mathrm{eq}\right.$.) with the copper reagents $\Gamma \mathrm{G}-\mathrm{RCu}(\mathrm{CN}) \mathrm{ZnI}\left((3 \mathrm{eq}),-78^{\circ} \mathrm{C}\right.$ to $-30^{\circ} \mathrm{C}$, $4 \mathrm{~h}$ ) in good yields $\left(72-90 \%\right.$; Scheme IV). By using the dicopper reagent $\mathrm{IZn}(\mathrm{CN}) \mathrm{Cu}\left(\mathrm{CH}_{2}\right)_{4} \mathrm{Cu}(\mathrm{CN}) \mathrm{ZnI} 1 \mathrm{i}$ which is

Scheme IV

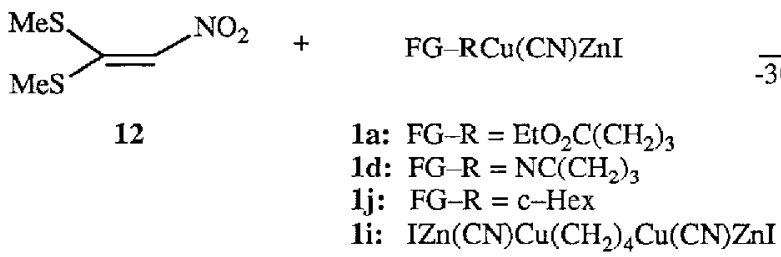

$\frac{\mathrm{THF}}{-30^{\circ} \mathrm{C}, 4 \mathrm{~h}}$

13a: $\mathrm{FG}-\mathrm{R}=\mathrm{EtO}_{2} \mathrm{C}\left(\mathrm{CH}_{2}\right)_{3} ; 90 \%$

13b: $\mathrm{FG}-\mathrm{R}=\mathrm{NC}\left(\mathrm{CH}_{2}\right)_{3} ; 86 \%$

13c: $\mathrm{FG}-\mathrm{R}=\mathrm{c}-\mathrm{Hex} \quad ; 72 \%$

13d: $\quad F G-R=-\left(\mathrm{CH}_{2}\right)_{4}-\quad ; 85 \%$

available in high yield from 1,4-diiodobutane (zinc dust ( $2.5 \mathrm{eq}.), 40^{\circ} \mathrm{C}, 2 \mathrm{~h}$ ), (nitromethylidene)cyclopentane $1513 \mathrm{~d}$ is obtained in $85 \%$ yicld.

In conclusion, we have shown that a variety of highly functionalized nitro olefins are available by the additionelimination of $\mathrm{RCu}(\mathrm{CN}) \mathrm{ZnI}$ to $\beta$-alkylthio and $\beta$-phenylsulfonyl nitro olefins in good to excellent yields. Extensions of these reactions are currently underway. 
Table I. Preparation of Polyfunctional Nitro Olefins and Nitro Dienes 3a-3k by the Reaction of (E)-1-nitro -2-phenyl sulfonylethylene $2 \mathrm{a}$ or 2-ethylthio-1-nitro-1-cyclohexene $2 \mathrm{~b}$ with $\mathrm{RCu}(\mathrm{CN}) \mathrm{ZnX}$.

Entry Organocopper reagent

a All yields refer to isolated yields of analytically pure products. Satisfactory spectral data (IR, ${ }^{1} \mathrm{H}$ and ${ }^{13} \mathrm{C} \mathrm{NMR}$, mass spectra, high resolution mass spectra) have been obtained for all compounds.

$b$ The crude reaction mixture also contained $c a$. $10 \%$ of $(E)$-3-acetoxy-4-methyl-1-(phenylsulfonyl)-1-pentene.

c $\mathrm{A}(1 E, 3 Z) /(1 E, 3 E)$ mixlure of $96: 4$ was obtained after distillation.

d The crude reaction mixture indicates a $(1 E, 3 Z) /(1 E, 3 E)$ ratio of $98: 2$ which becomes $14: 86$ after flash chromatography

e $\mathrm{A}(1 E, 3 Z) /(1 E, 3 E)$ mixture of $12: 88$ was obtained after flash chromatography.

$\mathrm{f}$ Obtained after flash chromatography as the pure $(E)$-isomer.

Acknowledgment: We thank the National Institutes of Health (GM-41908) for their generous support of this work and Dr. Peter Knoess for the preparation of some starting materials.

References and Notes:

1. Retherford, C.; Yeh, M.C.P.; Schipor, I.; Chen, H.G.; Knochel, P. J. Org. Chem. 1989, 54, 5200.

2. (a) Knochel, P.; Yeh, M.C.P.; Berk, S.C.; Talbert, J. J. Org. Chem. 1988, 53, 2390; (b) Berk, S.C.; Knochel, P.; Yeh, M.C.P. J. Org. Chem. 1988, 53, 5789; (c) Majid, T.N.; Knochel, P. Tetrahedron Lett. 1990, $31,4413$.

3. (a) Severin, T.; Scheel, D.; Adhikary, P. Chem. Ber. 1969, 102, 2966; (b) Severin, T.; Pehr, H. Chem. Ber. 1979, 112, 3559 and references cited therein; (c) Fuji, K.; Node, M.: Nagasawa, H.; Naniwa, Y.; Taga, T.: Machida, K.; Snatzke, G. J. Am. Chem. Soc. 1989, 111, 7921; (d) Fuji, K.; Node, M.; Nagasawa, H.; Naniwa, Y.; Terada, S. J. Am. Chem. Soc. 1986, 108, 3855; (e) Fuji, K.; Node, M.; Abe, H.; Itoh, A.; Masaki, Y.; Shiro, M. Tetrahedron Lett. 1990, 31, 2419; (f) Dell'Erba, C.; Mele, A.; Novi, M.; Petrillo, G.; Stagnaro, P. Tetrahedron Lett. 1990, 31 , 4933. 
4. (a) Ono, N.; Kamimura, A.; Kaji, A. J. Org. Chem. 1986, 51, 2139; (b) Fuji, K.; Khanapure, S.P.; Node, M.; Kawabata, T.; Ito, A. Tetrahedron Lett. 1985, 26, 779; (c) Tominaga, Y.; Ichihara, Y.; Hosomi, A. Heterocycles 1988, 27, 2345; (d) Kamimura, A.; Ono, N. Synthesis 1988, 921; (e) Jung, M.E.; Grove, D.D. J. Chem. Soc. Chem. Commun. 1987, 753; (f) Jung, M.E.; Grove, D.D.; Khan, S.I. J. Org. Chem. 1987, 52, 4570; (g) Hanessian, S.; Desilets, D.; Bennani, Y.L.J. Org. Chem. 1990, 55, 3098; (h) Node, M.; Kawabata, T.; Fujimoto, M.; Fuji, K. Synthesis 1984, 234.

5. (a) Ono, N., Kamimura, A.; Kaji, A. Tetrahedron Lett. 1986, 27, 1595; (b) see also ref. 4a.

6. Besides nitro olefins, several other classes of Michael acceptors having a $\beta$-alkylthio or a $\beta$-phenylsulfonyl group are known to undergo addition-elimination reactions with nucleophiles, see for example: (a) Dieter, R.K.; Silks, L.A. J. Org. Chem. 1983, 48, 2786; (b) Dieter, R.K.; Silks, L.A. J. Org. Chem. 1986, 51, 4687; (c) Dieter, R.K.; Lin, Y.J.; Dieter, J.W. J. Org. Chem. 1984, 49, 3183; (d) Dieter, R.K.; Fishpaugh, J.R.; Silks, L.A. Tetrahedron Lett. 1982, 23, 3751; (e) Najera, C.; Yus, M. Tetrahedron Lett. 1989, 30, 173; (f) Azzena, U.; Cossu, S.; De Lucchi, O.; Melloni, G. Tetrahedron Lett. 1989, 30, 1845; (g) Riera, A.; Marti, M.; Moyano, A.; Pericas, M.A.; Santamaria, J. Tetrahedron Lett. 1990, 31, 2173; (h) Schaumann, E.; Fittkau, S. Synthesis 1983, 449; (i) Back, T.G.; Collins, S.; Law, K.-W, Tetrahedron Lett. 1984, 25, 1689.

7. Typical procedure. (a) Improved preparation of $(E)$-1-nitro-2-phenylsulfonylethylene 2a. A mixture of (E)-1-nitro-2-phenylthioethylene ${ }^{4 \mathrm{a}}(9 \mathrm{~g}, 50 \mathrm{mmol})$ and $50-60 \% \mathrm{~m}$-chloroperbenzoic acid $(36 \mathrm{~g}, 104 \mathrm{mmol}$; dried as a solution in $\mathrm{CH}_{2} \mathrm{Cl}_{2}$ with $\mathrm{MgSO}_{4}$ ) in $600 \mathrm{~mL}$ of dry $\mathrm{CH}_{2} \mathrm{Cl}_{2}$ was stirred at $25^{\circ} \mathrm{C}$ for $12 \mathrm{~h}$. The reaction mixture was washed successively with water, aq. $\mathrm{NaOAc}$ solution and bine, then dried over $\mathrm{MgSO}_{4}$. After evaporation of the solvent, the crude yellow solid was recrystallized from THF/hexane to give $7.77 \mathrm{~g} \mathrm{(73 \% )}$ of analytically pure $2 \mathrm{a}$. (b) Addition of $\mathrm{RCu}(\mathrm{CN}) \mathrm{ZnI}$ to $\beta$-sulfonyl nitro olefins. Preparation of 6-nitro-5-hexenenitrile 3d (entry 4 of Table I). A solution of $2 \mathrm{a}(1.28 \mathrm{~g}, 6 \mathrm{mmol})$ in $10 \mathrm{~mL}$ of THF was added dropwise at $-78^{\circ} \mathrm{C}$ to a THF solution of the (3-cyanopropyl)copper derivative $1 \mathrm{~d}$ prepared as reported previously. ${ }^{1,2}$ The reaction mixture was warmed to $-50^{\circ} \mathrm{C}$, quenched after $5 \mathrm{~min}$. with a sat. $\mathrm{NH}_{4} \mathrm{Cl}$ solution and worked up as usual. Flash chromatography purification of the resulting crude oil (10:10:1 hexane:dichloromethane:ethyl acetate) gave $710 \mathrm{mg}$ of pure 3d (85\%). In the case of $2 \mathbf{b}$, the reaction mixture was warmed to $25^{\circ} \mathrm{C}$ and stirred $12 \mathrm{~h}$ at this temperature.

8. (a) Knochel, P.; Chou, T.-S. J. Org. Chem. 1990,55, 4791; (b) Knochel, P.; Chou, T.-S.; Chen, H.G.; Yeh, M.C.P.; Rozcma, M.J. J. Org. Chem. 1989, 54, 5202 .

9. Retherford, C.; Chou, T.-S.; Schelkun, R.M.; Knochel, P. Tetrahedron Lett. 1990, 31, 1833.

10. (Z)-1-Iodo-1-hexene (prepared according to Alexakis, A.; Cahiez, G.; Normant, J.F. Org. Synth. 1984, 62, 1) was converted to (Z)-1-lithio-1-hexene (Cahiez, G.; Bernard, D.; Normant, J.F. Synthesis 1976, 245) and treated successively with zinc iodide (1 eq.) in THF/Et $2 \mathrm{~S}(1: 1)$ at $-78^{\circ} \mathrm{C}$; after warming to $25^{\circ} \mathrm{C}$, the mixture is added to a solution of a $\mathrm{CuCN} \cdot 2 \mathrm{LiCl}$ (1 equiv.) in $\mathrm{THF} / \mathrm{Et}_{2} \mathrm{~S}(1: 1)$ at $-78{ }^{\circ} \mathrm{C}$. The use of these conditions is crucial for the formation of a stable vinylic copper reagent. The two following reaction conditions, $\mathrm{A}$ : $\mathrm{CuCN} \cdot 2 \mathrm{LiCl}$ ( 1 eq.) in $\mathrm{Et}_{2} \mathrm{~S}$, $-78^{\circ} \mathrm{C}$ to $-30^{\circ} \mathrm{C}$, or $\mathrm{B}$ : (i) $\mathrm{ZnI}_{2}(1 \mathrm{eq}$.), THF; (ii) $\mathrm{CuCN} 2 \mathrm{LiCl}(1 \mathrm{eq}),. \mathrm{THF}$, are not satisfactory and lead to an extensive dimerization of the alkenylcopper.

11. For an alternative preparation of nitro dienes see: Bloom, A.J.; Mellor, J.M. Tetrahedron Lett. 1986, $27,873$.

12. The copper reagent 4 was prepared from 1-iodo-4,6-octadiene (zinc dust ( $3.0 \mathrm{eq}$.), THF, $40^{\circ} \mathrm{C}, 4 \mathrm{~h},>85 \%$ yield); for the preparation of 4,6-octadienol from sorbic acid see: (a) Jacobson, M. J. Am. Chem. Soc. 1955, 77, 2461; (b) Hudlicky, T.; Koszyk, F.J.; Kutchan, T.M.; Sheth, J.P. J. Org. Chem. 1980, 45, 5020; (c) for the conversion of 4,6-octadienol to 1-iodo-4,6-octadiene: Scheffold, R.; Saladin, E. Angew. Chem. Int. Ed. Engl. 1972, 11, 229 .

13. (a) Ciganek, E. Org. React. 1984, 32, 1-374, John Wiley, New York. The attribution of the relative stereochemistry in compound 6 is based on the ${ }^{1} \mathrm{H}$ NMR experiments: ${ }^{3} \mathrm{~J}_{\mathrm{H} 1, \mathrm{H} 2}=11.5 \mathrm{~Hz},{ }^{3} \mathrm{~J}_{\mathrm{H} 2, \mathrm{H} 3}=11.7 \mathrm{~Hz},{ }^{3} \mathrm{~J}_{\mathrm{H} 3, \mathrm{H} 4}=7 \mathrm{~Hz}$. To confirm the assignment of the relative stereochemistry between $\mathrm{H}_{3}$ and $\mathrm{H}_{4}, 6$ was hydrogenated giving ${ }^{3} \mathrm{~J}_{\mathrm{H} 3, \mathrm{H} 4}=5 \mathrm{~Hz}$ (Scheme II); see: (b) Roush, W.R. J. Am. Chem. Soc. 1980, I02, 1390; (c) Parlar, H, Baumann, R. Angew. Chem. Int. Ed. Engl. 1981, 20, 1014; (d) Kurth, M.J.; O'Brien, M.J.; Hope, H.; Yanuck, M. J. Org. Chem. 1985, 50, 2626.

14. In order to prove a possible radical mechanism for the addition-elimination reaction of nucleophiles to (E)-1-nitro-2-phenylsulfonylethylene $2 \mathrm{a}$, the two following reactions were performed: (a) lithium ethanethiolate was added at $-78^{\circ} \mathrm{C}$ to $2 \mathrm{a}$. The solution was stirred for $5 \mathrm{~min}$. and worked up as usual. (E)-2-ethylthio-1-nitro ethylene and $(E)$-2-ethylthio-1-phenylsulfonylethylene were obtained in a 1:4 ratio (75\% yield); (b) the same reaction was performed in the presence of $5 \mathrm{~mol} \%$ of di-tert-butylnitroxide (see: Komblum, N. Angew. Chem. Int. Ed. Engl. $1975,14,734$ ) leading to the same product distribution and ruling out a radical mechanism.

15. Cunino, R.F. J. Org. Chem. 1990, 55, 4474 and references cited therein. 